\title{
Coastal Erosion in Yasawa Islands, Fiji
}

\author{
Nils-Axel Mörner ${ }^{1}$, Pamela Matlack Klein ${ }^{2}$ \\ ${ }^{1}$ Paleogeophysics \& Geodynamics, Stockholm, Sweden; ${ }^{2}$ The Portuguese Sea Level Project, Appomattox, Virginia, \\ USA
}

Correspondence to: Nils-Axel Mörner, morner@pog.nu; Pamela Matlack Klein, pmkdragon@gmail.com

Keywords: Coastal Erosion, Currents, Jetties, Sea Cucumbers, Stable Sea Level, Fiji

Received: April 6, $2017 \quad$ Accepted: May 24, $2017 \quad$ Published: May 27, 2017

Copyright $\odot 2017$ by authors and Scientific Research Publishing Inc.

This work is licensed under the Creative Commons Attribution International License (CC BY 4.0).

http://creativecommons.org/licenses/by/4.0/

\section{(c) (i) Open Access}

\section{ABSTRACT}

Coastal erosion may have many different causes. Wherever we came across erosion problems on the Yasawa Islands in Fiji, they had causes other than sea level rise. We present two case studies. At one site, the beach erosion was caused by the construction of a stonewall diverting the currents in a gyre that hit the shore causing local beach erosion. At another site, extensive erosion caused removal and lateral re-deposition of huge quantities of sand. From the Google Earth images we can infer a date between 2005 and 2009 for this change in shore conditions. We suggest that the shallow-water sand was destabilized by the commercial harvesting of thousands of sea cucumbers (Holothuria scabra). These animals, by their sheer numbers and ecological behavior, were exerting a stabilizing influence on the shallow-water sandy deposits off the beach at Yageta Village. In both cases, the erosion was caused by human action. The coasts all along the Yasawa Islands are characterized by coastal stability. The presence of extensive rock-cut platforms and notches, as well as the occurrence of corals grown into "mini-atolls" are indicative of a stable sea level throughout the islands.

\section{INTRODUCTION}

Ocean coasts are always susceptible to coastal erosion. The reason for this is manifold. Coastal erosion is by no means a simple result of sea level rise [1] as often claimed. Instead, coastal erosion may be caused by many different natural processes like changes in prevailing wind direction, coastal currents, re-establishment of a new equilibrium profile, sea level rise, sea level fall, exceptional storms, hurricanes/cyclones, and tsunami events. Coastal erosion is also caused by human interference with coastal processes.

In this paper we will analyze examples of coastal erosion in the Yasawa Islands, an island chain consisting of about ten major islands and lots of small islands to the northwest of Viti Levu, the main island of Fiji. In March 2017, we visited 9 of those islands in association with an international project on changes in sea level [2]. Though the shores in general exhibit strong coastal stability, there are, of course, also exam- 
ples of coastal erosion.

\section{GENERAL COASTAL STABILITY}

In general, the beaches and shorelines of the Yasawa Islands exhibit a strong coastal stability. The rocky coasts have a distinct rock-cut platform, often with sea caves, both indicating a time of, at least, decades of stable sea level conditions. The high-tide accumulation of sand corresponds very well in elevation to the rock-cut platform (Figure 1). The occurrence of "mini-atolls" some $40-60 \mathrm{~cm}$ below low-tide level is also indicative of a stable sea level over the past decades [2].

\section{EROSION AT LONG SANDY BEACH}

On the Island of Matacawa Levu, there is a resort known as Long Sandy Beach. Here, there is a segment of the beach that suffers erosion (Figure 2). In this case, we know exactly what had happened; extensive jetties (Figure 3 ) were built, which altered the coastal currents leading to erosion over a limited area of the beach (Figure 2).

We can follow the changes from the succession of Google Earth images (Figure 4). In 2005, the coastal longshore-drift moved the sand eastwards (Figure 4(a)). In 2009, the jetties had been installed, and

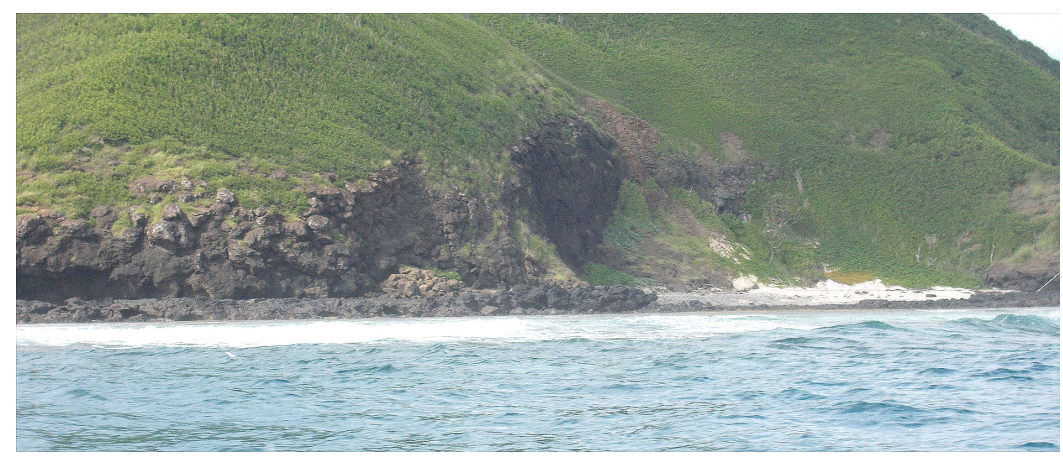

Figure 1. Typical shore segment from the Yasawa Islands. The high-tide level (HTL) is marked by a distinct rock-cut platform with undercut-notches and sea caves, and a sharp notch on the sandy beach. This is indicative of coastal stability.

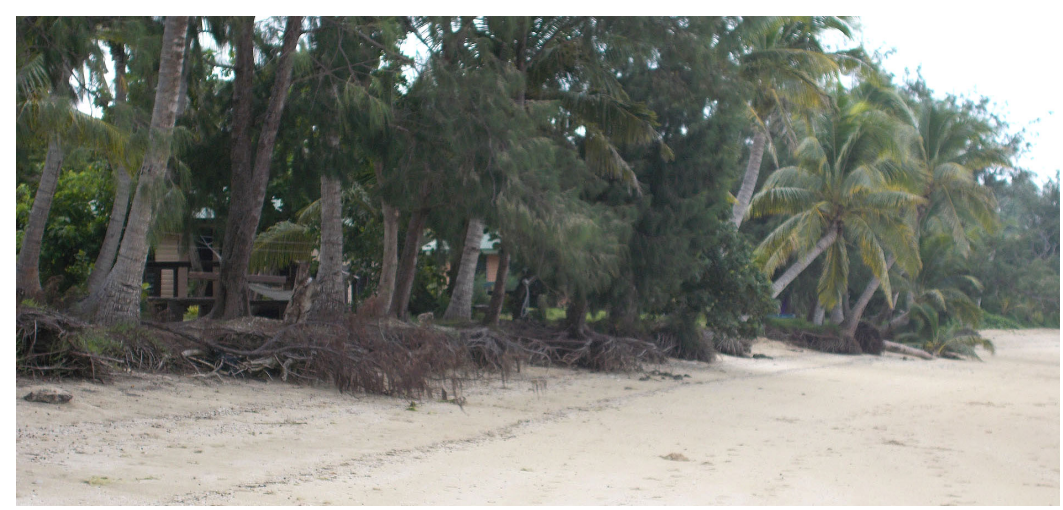

Figure 2. Erosion at Long Sandy Beach due to redirected coastal currents. The redirection of currents was caused by the error of building a jetty. The photo was taken at low tide, with the HTL visible as a dark line on the beach. 


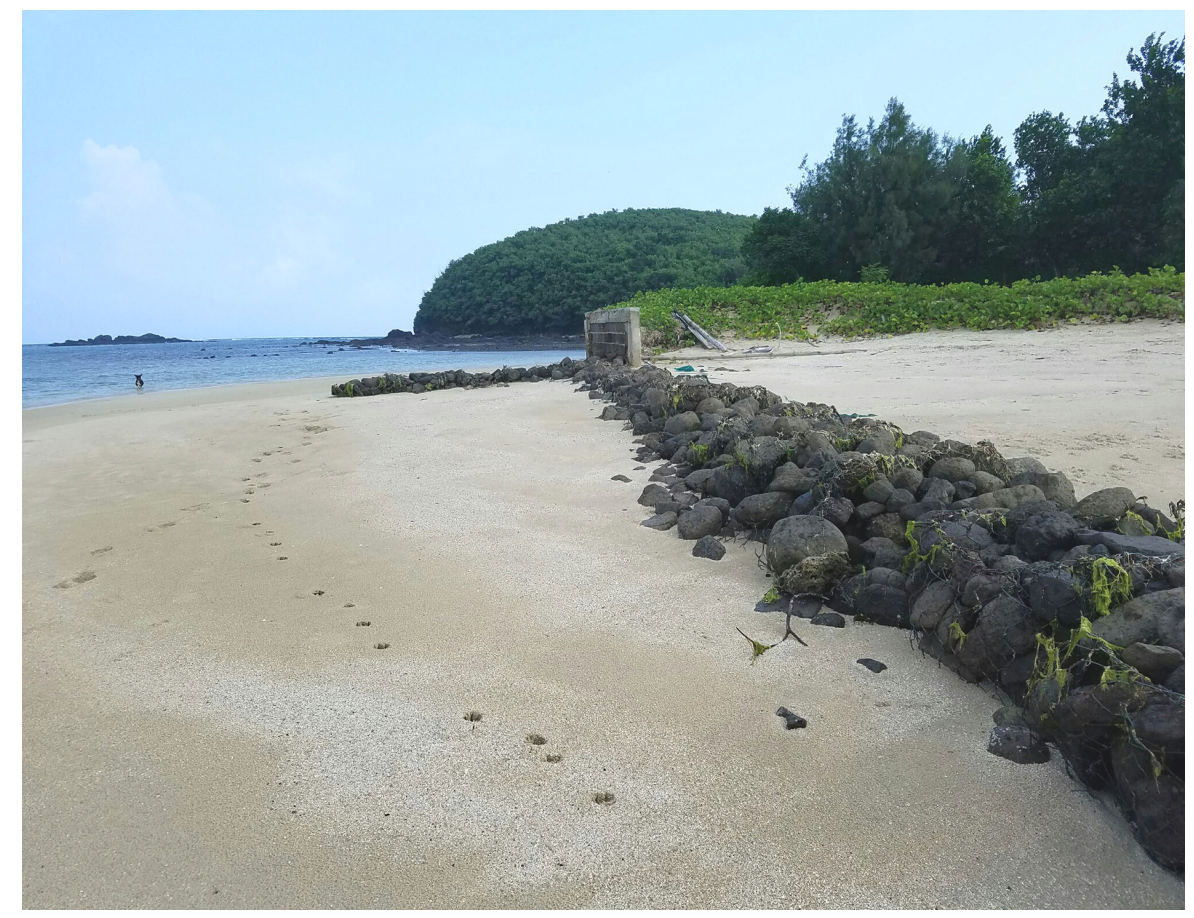

Figure 3. Jetties were built in order to extend the resort area. This blocked the existing coastal longshore-drift and current direction, which led to a reversed circulation with a gyre hitting the shore just where the erosion (Figure 2) occurred. Photo taken at low tide.

the longshore transport seems to have stopped (Figure 4(b)). In the image from 2016 (Figure 4(c)), a reversal of the original coastal current transport is recorded. Now there is a strong transport to the west. Obviously this change in coastal current direction and motion of sediments is linked to a gyre in the current, turning to the beach, where it caused coastal erosion (Figure 2) over a distance of a few tens of meters; i.e. just where the current hit the shore.

This implies that it was the installation of jetties, which was the ultimate cause of erosion at Long Sandy Beach. That, in turn, implies that it was human error that generated the erosion. To blame "sea level rise" (which we heard some of the locals involved in the jetty installation say), is simply incorrect.

The main jetty cutting the original longshore-drift, and altering the currents (Figure 3) should be removed.

The installation of jetties and protective stonewalls is always dangerous for the simple reason that coastal processes are complicated to judge accurately. Therefore, such installations often lead to unwanted results. Long Sandy Beach is unfortunately one examples of how well-meaning intentions can produce adverse effects.

\section{EROSION AT YAGETA VILLAGE}

At Yageta Village on Matacawa Levu Island, there is quite severe coastal erosion going on. Already before going to Fiji, we had observed on the Google Earth image that something odd was going on along the coast of Yageta Island with huge quantities of sand accumulating to the north-east of the village beach [3].

The erosion along the shore of Yageta Village is quite severe as shown in Figure 5. It started some years ago without any connection to any special events like a cyclone, an extreme storm or a tsunami.

The accumulation of sand to the northeast is very extensive. It seems quite odd on the Google Earth 

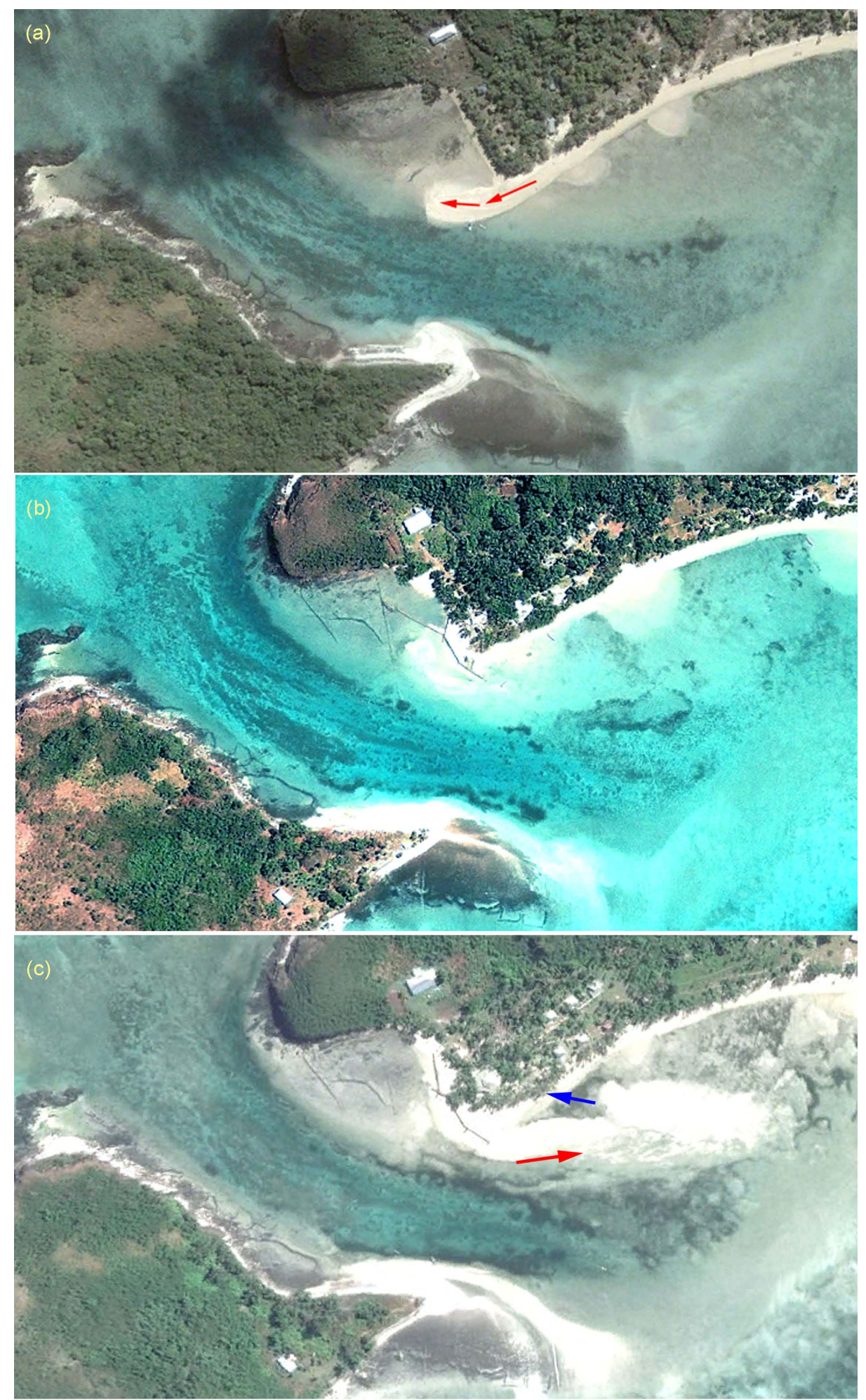

Figure 4. Cartoon of Google Earth images: from 2005 (a), 2009 (b) and 2016 (c). In 2005, the shore was built out to the north-east. In 2009, the jetties had been installed, and the coastal transport was interrupted. In 2016, the coastal current is reversed to the north-west, and a gyre of the current hits the shore and causes local erosion. 


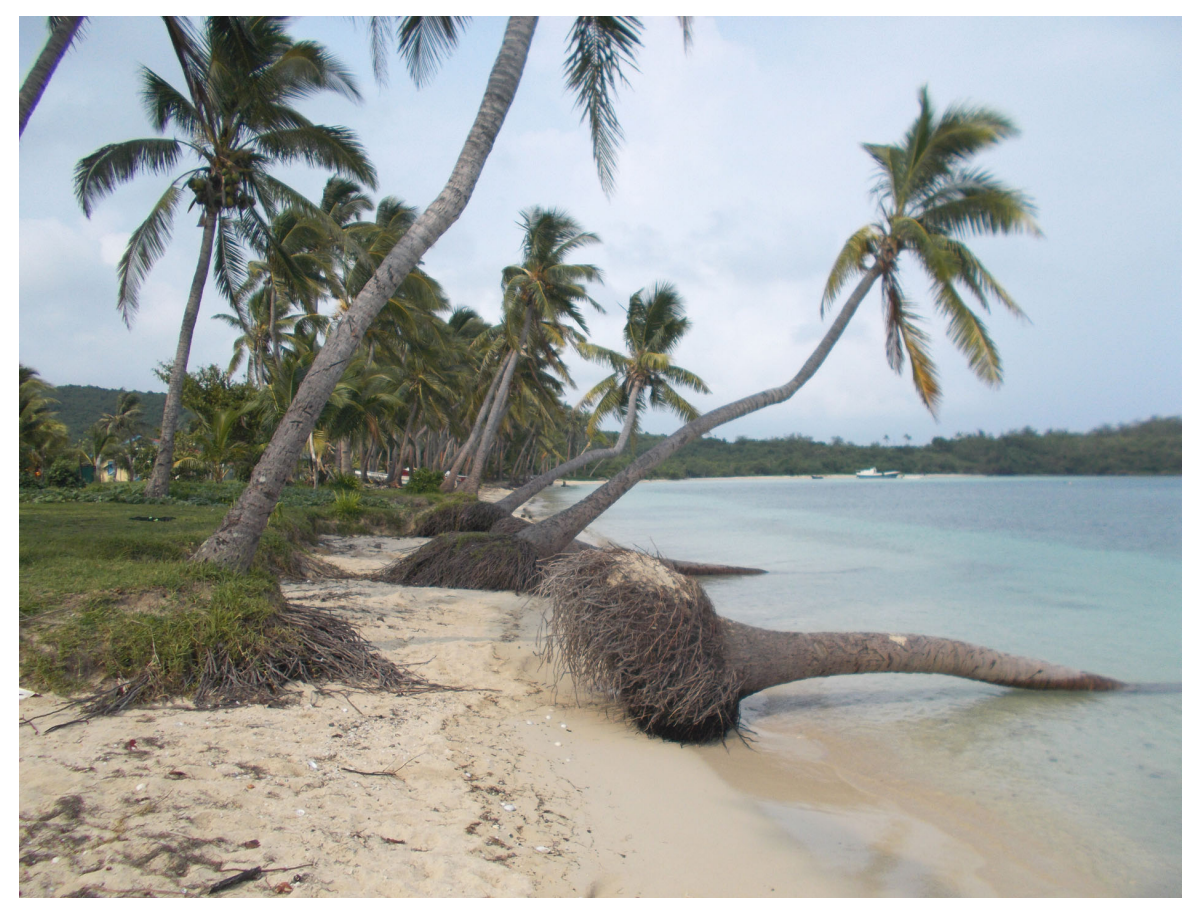

Figure 5. Erosion and beach damage along the shore of Yageta Village. The sand removed was transported north-eastwards and formed a huge accumulation where the boat is in the background.

image, suggesting a young deposition not yet properly redistributed with respect to currents, waves and tides.

Looking at different Google Earth images, it was easy to see that the erosion and building up of re-deposited sand in the bay to the northeast occurs in the image of August 24, 2009, but not in the image of July 8, 2005. This indicates that the change in sedimentation took place between 2005 and 2009.

To begin with we were unable to discern what could have caused this change in sedimentation. From our own studies, we were sure it could have nothing to do with a rise in sea level $[2,4]$. Cyclone Winston struck the area much later (on February 20, 2016), so this event can be excluded.

We discussed the issue with the village chief Moapi Seuseu. When he said: "can it have anything to do with the fact that we have collected thousands and thousands of sea cucumbers from the shore, and sold them to Japan", we both felt a flash of enlightenment.

The sea cucumbers in question are Holothuria scabra, locally known as "sandfish" or "golden sandfish" [3].

They are an important part of the local fishery and economy of the Fiji islands. They are harvested, gutted, dried and then sold to China and Japan as "bêche-de-mer".

Casual observations of the animal at low tide, showed it to be indigenous to shallow waters where it feeds on detritus during the day, expelling clean sediments as a waste product. They secrete a sticky substance from their skin that causes sediment particles to adhere to their bodies, allowing them to blend into their environment [3]. They burrow into the sand at night (between 03 and 09 o'clock), and feed actively from 15 to 03 o'clock.

Feeding is accomplished by slowly moving over the surface of the sediments, ingesting sand particles and detritus, which is stripped of nutrients, then expelled as clean sediment. The density of the sea cucumber population outside Yageta Village suggests that this might have been a major factor in stabilizing the sand along the shore of Yageta Village $[3,5]$.

Therefore, our conclusion is that the removal of the dense population of sea cucumbers along the 
shore of Yageta Village was the ultimate cause of the change in sedimentary conditions, causing erosion along the village beach (Figure 5) and giving rise to vast accumulation of sand to the northeast (Figure 6) [3].

\section{DISCUSSION}

Coastal erosion may be caused by several different factors [1]. Coastal erosion sporadically occurs on the Yasawa Islands in Fiji.

The predominant picture, however, is very strong coastal stability (Figure 1). The HTL is often associated with a distinct rock-cut platform, undercut notches and sea caves. Similarly, there are several coastal spits and barriers, which must have required multi-decadal time frames of formation. Leveling indicates unchanged conditions during the time of formation. Besides, we have found several examples of corals grown as "mini-atolls" because they are located only $40-60 \mathrm{~cm}$ below LTL placing a limit on their vertical growth.

The two examples of coastal erosion here highlighted were found to have origins other than sea level rise.

Mimura and Nunn [6] studied the problem of coastal erosion at 25 sites on the Island of Viti Levu, and 4 sites on the Island of Taveuni. They concluded that the erosion was initiated "mainly by human-induced causes", which agrees well with our results from the Yasawa Islands.

\section{CONCLUSIONS}

The coastal erosion at Long Sandy Beach was initiated by the building of jetties, which generated a reversal of the coastal current and direction of sand transport (Figure 4). A gyre of the current became directed straight on-shore. This led to local erosion.

At Yageta Village quite severe erosion (Figure 5) and re-deposition of sand (Figure 6) occurred. It seems that this was initiated by the removal of "thousands and thousands of sea cucumbers" affecting the stability of the sand off the beach of the village.

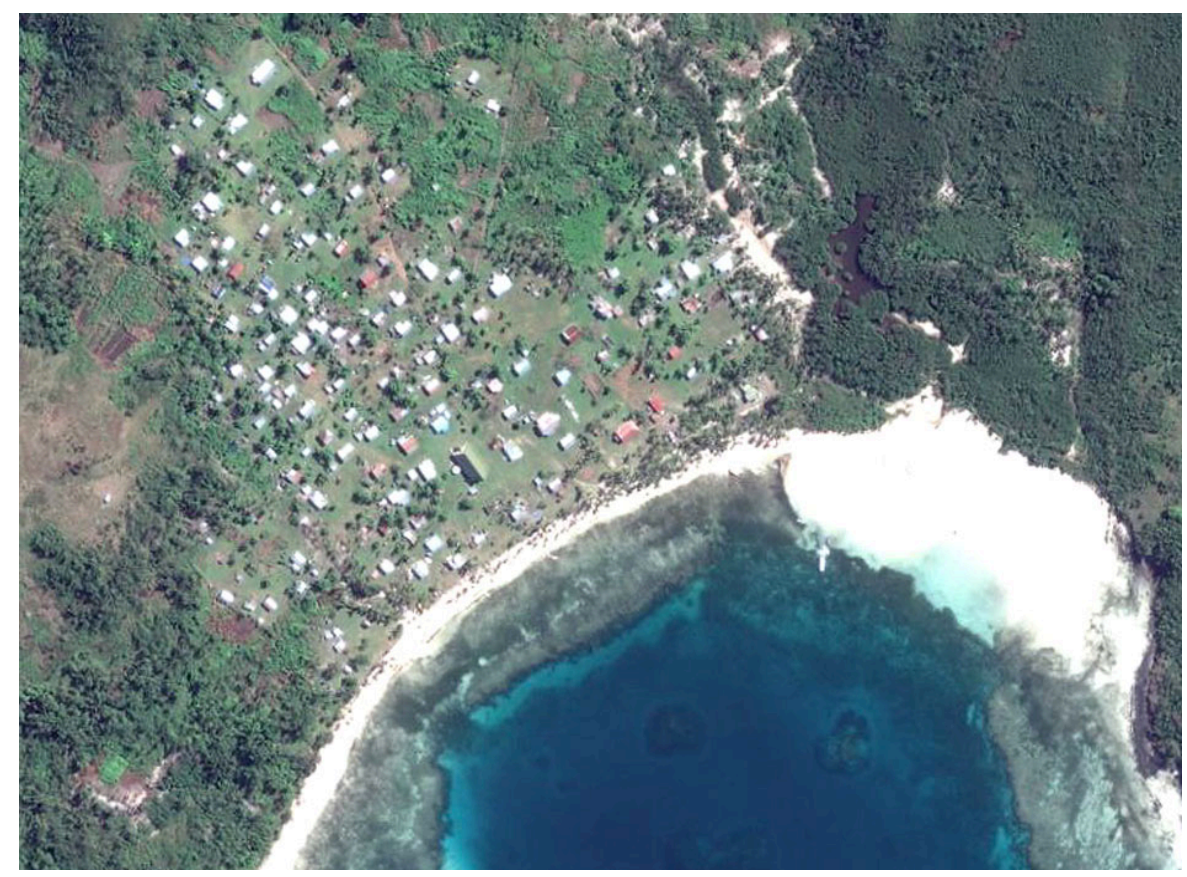

Figure 6. The sand eroded and removed from the village beach was deposited in a huge accumulation in the embayment to the northeast. 
In both cases we see the effects of human interference with the coastal sedimentary conditions. To escape responsibility by blaming sea level rise is incorrect, from a scientific as well as geoethic point of view.

\section{ACKNOWLEDGEMENTS}

This is Paper 2 of The Fiji New Sea Level Project. It refers to fieldwork undertaken during March $1-16,2017$. The project was supported by a kind grant from the $\mathrm{CO}_{2}$ Coalition.

\section{REFERENCES}

1. Mörner, N.-A. (2015) Coastal Erosion and Coastal Stability. In: Barens, D., Ed., Coastal and Beach Erosion, Nova Science Publishers, New York, 69-82.

2. Mörner, N.-A. and Matlack Klein, P. (2017) The Fiji New Sea Level Project. ResearchGate, https://www.researchgate.net/publication/315490083_The_Fiji_New_Sea_Level_Project

3. Mörner, N.-A. and Matlack Klein, P. (2017) Shore Erosion in Yageta Village: Observations, Interpretation and Proposal. Internal Report to the Village Chief. ResearchGate, April 4.

https://www.researchgate.net/publication/315778427

4. Mörner, N.-A. (2017) Coastal Morphology and Sea Level Changes in Goa, India, during the Last 500 years. Journal of Coastal Research, 33, 42-434. https://doi.org/10.1080/028418501127346846

5. Altamirano J.P., Recente, C.P. and Rodriguez Jr., J.C. (2016) Substrate Preference for Burying and Feeding of Sandfish Holothuria scabra juveniles. Fisheries Research, 186, 514-523. https://doi.org/10.1016/j.fishres.2016.08.011

6. Mimura, N. and Nunn, P.D. (1998) Trends of Beach Erosion and Shoreline Protection in Rural Fiji. Journal of Coastal Research, 14, 37-46.

\section{Submit or recommend next manuscript to SCIRP and we will provide best service for you:}

Accepting pre-submission inquiries through Email, Facebook, LinkedIn, Twitter, etc.

A wide selection of journals (inclusive of 9 subjects, more than 200 journals)

Providing 24-hour high-quality service

User-friendly online submission system

Fair and swift peer-review system

Efficient typesetting and proofreading procedure

Display of the result of downloads and visits, as well as the number of cited articles

Maximum dissemination of your research work

Submit your manuscript at: http://papersubmission.scirp.org/

Or contact ns@scirp.org 